TURIZAM

Volume 24, Issue 2

$57-67$ (2020)

ORIGINAL

SCIENTIFIC PAPER

\title{
Expectations and Satisfaction of Hospitality Students with Employment in Hospitality Industry
}

\author{
Milan Ivkov ${ }^{A}$, Viktorija Simon ${ }^{A^{*}}$, Jelena Tepavcevic ${ }^{A}$, Ilinka Stojkovic ${ }^{A}$ \\ Received:Januar 2020 | Accepted: March 2020 \\ DOI: $10.5937 /$ turizam\%v-24810
}

\begin{abstract}
Education, complex skills and specialized knowledge of employees are crucial in industries such as hospitality industry. Students of hotel management in various ways try to acquire the experience necessary for employment, such as: professional practice, student exchange, attendance at specialized courses, etc. The importance of human resources both in hospitality industry and in service industries in general, is constantly growing. The main goal of this paper is to determine the expectations and satisfaction of hotel management students with employment in the hospitality industry. The survey was conducted among former and current students of hotel management of the Faculty of Sciences in Novi Sad. The results revealed statistically significant differences in responses. Theoretical and practical implications are discussed in order to help scholars and practitioners better understand this topic.
\end{abstract}

Keywords: Hospitality industry, Job expectation, Job satisfaction, Students

\section{Introduction}

Nowadays, the hospitality is cited as one of the most fascinating and fun industry to work. This is an industry that is open 24 hours a day and 365 days a year (Walker, 2007). It is generally accepted attitude that human resources are the greatest competitive advantage on the market. They are the key element in the hospitality industry because they are communicating with guests and deliver most of the service (Kong et al., 2018). Hospitality requires wide range of different professional profiles and educational levels of employees.

According to data of the Statistical Office of the Republic of Serbia from 2018 the hospitality industry had the largest proportion of employees with secondary education (total $45.30 \%$ ), while the share of employees with completed higher education school is only $5 \%$. According to the same data, the share of employees with degree is $10.70 \%$. A disadvantage is that a considerable number of employees with secondary education occupy top management positions in hotels and restaurants. One of the major problems in the modern hospitality industry of the Republic of Serbia is the lack of competent managers, who have sufficient knowledge, interna-

A University of Novi Sad, Faculty of Sciences, Department of Geography, Tourism and Hotel Management, Trg Dositeja Obradovica 3, 21000 Novi Sad, Serbia; Corresponding author: simon.viktorija@gmail.com 
tional experience in the hospitality industry and special abilities and skills necessary for managing hotel operations (Blagojević, Redžić, 2009).

One of the problems of working in the tourism sector is that there are two types of jobs in the industry, two different extremes. There are a large number of those jobs that are poorly paid and require low skills, while a small number of positions require a highly skilled people who are generally well-paid (Macdonald, Sirianni, 1996).

National Opinion Research Center at the University of Chicago conducted a survey in 2007 on employee satisfaction in the US. The results showed that employees in the hospitality industry are among the most dissatisfied. The degree of satisfaction for employees in the food and beverage sector was below $30 \%$ : chefs $-24 \%$, bartenders - $26 \%$, waiters and servers $-27 \%$ (Smith, 2007). Annual quits rates in tourism and hospitality industry is the highest among all industries in the US every year from 2015 until 2019 (U.S. Bureau of Labor Statistics, 2020).

It is very important to identify the key components of dissatisfaction, to take specific steps to eliminate them and more frequently measure job satisfaction, in order to determine and monitor its level and progress (Kosar, Rašeta, 2005). Extraordinary service is usually provided by an employee who is satisfied with the job (Knox et al., 2003). Lower service quality may be provided by employees who are not satisfied with job (McPhail et al., 2015). The impact of employees on service quality in the hospitality industry is obvious, because only satisfied employees can make the guest happy (Kosar, 2009). Working conditions in the tourism and hospitality industry differ from country to country and from company to company (Đeri, 2009). Jobs in hotel industry are not easy at all (Cheng, O-Yang, 2018). Working in tourism and hospitality is considered as stressful and people employed in this industry cannot balance between job and personal life (O'Neill, Xiao, 2010). There are often long shifts and overtime, level of job security is low, work schedules are not regular and flexible, a lot of working weekends and holidays, the job is low-paid (Karatepe et al., 2012; Karatepe, Bekteshi, 2008; Karatepe et al., 2008; Karatepe, Uludag, 2008). Job burnout is one more thing that can cause dissatisfaction with job in the hospitality industry (Lee, Ok, 2012) and it is very common because service employees often deal with difficult customers (Kim, 2008). Also, it has been noticed that friendly and well-disposed frontline employee could generate many desirable effects on organization, such as customer satisfaction, loyalty and commitment, customer retention as well as customer willingness to spread the positive word-of-mouth (Groth et al., 20o9; Hartline, Ferrel, 1996; Tsai, 2001; Tsai, Huang, 2002).

\section{Methodology and research description}

The survey was conducted among former and current students of hotel management of the Faculty of Sciences in Novi Sad in September 2018. All respondents were employed in Republic of Serbia at the moment of their participation in the study. An online questionnaire was created in Google Docs and it was distributed via social networks. The study sample consists of 55 respondents.

The questionnaire consists of three parts. The first part of the questionnaire is related to the profile of participants. The second part focuses on the expectations that students had with the employment in the hospitality industry and the third part of the questionnaire is related to their satisfaction with employment in the same industry.

For the purpose of this research, a model designed by De Beer (1987) was used. The initial model comprised of 43 items and nine dimensions: Work Content, Payment, Promotion, Rec- 
ognition, Working Conditions, Benefits, Personal, Supervisor and Desire to quit the job. However, the initial model has been modified for this research and consists of 40 items and eight dimensions. The last, ninth dimension Desire to quit the job was omitted. All eight dimensions appear in both the second and the third part of the questionnaire.

Each of the statements, in the second and third part of the questionnaire, had five possible answers from which respondents could choose the one that best suits their attitude or feeling at the given moment. A five-point Likert scale is used for assessing the statements: (1)-strongly disagree, (2)-disagree, (3)-neither agree nor disagree, (4)-agree, (5)-strongly agree. Reliability of the modified questionnaire was tested by calculating the reliability coefficient (Cronbach's Alpha). It can be concluded that used questionnaire is reliable given that the coefficient for the scale of 40 questions concerning expectations is 0.902 , while the scale of 40 questions regarding satisfaction coefficient is 0.944 (Hinton et al., 2004).

\section{Sample description}

Based on the analysis of the sample, it can be noted that more than a half of the respondents have a master's degree (Table 1). It can be also seen that more than the half of respondents are those who are in the industry up to three years. On the other hand, just few respondents have been working in the hospitality industry for up to nine years, which coincides with the fact that most students start their career at the end or after graduation. The largest number of respondents is employed in reception (40\%) and restaurant (34.5\%).

Table 1. Socio-demographic characteristics of the respondents $(N=55)$

\begin{tabular}{|l|c|c|}
\hline \multicolumn{2}{|c|}{ Number } & Percent \\
\hline Level of education acquired & 8 & $14.5 \%$ \\
\hline Current student & 17 & $30.9 \%$ \\
\hline Bachelor's degree & 30 & $54.5 \%$ \\
\hline Master's degree & 12 & $21.8 \%$ \\
\hline Length of work experience in the hospitality industry & $52.7 \%$ \\
\hline Up to a year & 29 & $18.2 \%$ \\
\hline Up to three years & 10 & $7.3 \%$ \\
\hline Up to six years & 4 & \\
\hline Up to nine years & 9 & $16.4 \%$ \\
\hline The hospitality sector in which respondent is employed & $34.5 \%$ \\
\hline Kitchen & 19 & $40 \%$ \\
\hline Restaurant & 22 & $9.1 \%$ \\
\hline Reception & 5 & \\
\hline Marketing and Sales & & \\
\hline
\end{tabular}




\section{Results and discussion}

\section{Results of T-test}

T-test for independent samples was used to compare the mean values of acquired results. Tables presented below show those dimensions where statistically significant differences exist in responses between two different groups of participants.

Results of T-test according to gender show that there are statistically significant differences in responses of male and female participants. Female participants may have higher expectations, but on the other hand, male participants are generally less satisfied (Table 2).

The analysis of answers for dimension Working conditions, leads to conclusion that female participants have higher expectations. Women expect more flexibility when talking about working hours and overtime and this is usually due to their other daily tasks, household and child care (Reisch, 2017). Next to that, it is often important to women to socialize and to be accepted at work.

Further results show that female participants are more satisfied with dimension Work content, than male participants, so it is not surprising that they are probably more motivated for work and more interested in job promotion and therefore more satisfied with dimension Promotion.

Analyzing the results for dimension Benefits it can be seen that there are statistically significant differences between answers of male and female participants, where women are more satisfied.

As a result of stereotypes, men are usually considered natural leaders (Holmes, 2019). This has created their need to be at leader positions, so it is not surprising that they gave noticeably lower ratings $(M=2.3333)$ to statement "I am given work in accordance with my qualifications and skills" than female participants $(\mathrm{M}=3.5581)$.

Table 2. T-test according to gender

\begin{tabular}{|l|c|c|c|c|}
\hline \multirow{2}{*}{ Dimensions } & \multicolumn{2}{|c|}{ Mean } & \multirow{2}{*}{ t } & P \\
\cline { 2 - 3 } & Female $(\mathrm{n}=43)$ & Male $(\mathrm{n}=12)$ & & $0.020^{*}$ \\
\hline D5-Working conditions (expectation) & 3.7442 & 3.1667 & 2.393 & $0.024^{*}$ \\
\hline D1-Work content (satisfaction) & 3.7100 & 3.1569 & 2.506 & $0.004^{*}$ \\
\hline D3-Promotion (satisfaction) & 3.2791 & 2.1389 & 2.981 & $0.004^{*}$ \\
\hline D5-Working conditions (satisfaction) & 3.1318 & 2.2222 & 3.024 & $0.030^{*}$ \\
\hline D6-Benefits (satisfaction) & 3.3179 & 2.4167 & 2.225 & $0.034^{*}$ \\
\hline D7-Personal (satisfaction) & 3.5233 & 2.7083 & 2.177 & \multirow{2}{*}{} \\
\hline
\end{tabular}

$p<0.05$

Participants within the age category 21-25 years, have lack of experience in hospitality industry what boosts their expectations in regard to working conditions $(M=3.7879)$. Opposite to them, participants within the age category 26-30 years who have previous work experience, gave lower marks $(M=3.3636)$, which represents statistically significant difference between two groups $(\mathrm{t}=2.058, \mathrm{p}=0.044)$. It can be concluded that younger participants are still optimistic and euphoric while older participants have more experience and they know much better what to expect from working in this industry.

It is also noticeable that participants that have been working up to three years in the current company, are more satisfied with their job and department $(M=3.7500)$ than participants 
that are in the company up to a year $(M=3.1143)$, which indicate statistically significant difference between these two groups of respondents $(t=-2.180, p=0.034)$. The reason for that may be that those who work longer in the same company have gained trust of employers and proved their qualities and skills.

The results of T-test according to type of participants' employment (permanent and temporary) are shown in Table 3. Permanent employees have higher expectations about supervisors than those who are temporary employed. The reason may be that they are aware they will probably work in company for a longer period so for them relations with their supervisors are very important. Furthermore, permanent employees know their supervisors and managers for a longer period of time, the connection between them is stronger, they have built mutual trust and they appreciate each other. On the other side, those who are temporary employed struggle to create such relationship with supervisors, due to short period of time spent in the company.

In practice, promotion of a temporary employee happens rarely. According to that, these employees are less satisfied with work content than permanent workers. Another reason for this is because this type of a job is usually less valued and people are less paid accordingly.

Companies usually engage temporary workers for jobs and tasks that had been previously defined. It is very rare occasion when those persons can choose department and job according to qualifications and skills they have. Because of that, temporary employed staff are less satisfied with dimension Personal than those who are employed for a longer period of time and who are probably employed due to their qualifications and skills.

Table 3. T-test according to type of participants' employment

\begin{tabular}{|c|c|c|c|c|}
\hline \multirow{2}{*}{ Dimensions } & \multicolumn{2}{|c|}{ Mean } & \multirow{2}{*}{$\mathrm{t}$} & \multirow{2}{*}{$\mathrm{P}$} \\
\hline & Permanent employees $(n=30)$ & Temporary employees $(n=25)$ & & \\
\hline D8-Supervisors (expectation) & 4.5167 & 4.1400 & 2.420 & $0.019 *$ \\
\hline D1-Work content (satisfaction) & 3.8824 & 3.2376 & 4.288 & $0.000 * *$ \\
\hline D3-Promotion (satisfaction) & 3.5667 & 2.3867 & 3.906 & $0.000 * *$ \\
\hline D4-Benefits (satisfaction) & 3.4889 & 2.6800 & 2.427 & $0.019 *$ \\
\hline D7-Personal (satisfaction) & 3.8333 & 2.7600 & 3.718 & $0.000^{* *}$ \\
\hline D8-Supervisors (satisfaction) & 4.1167 & 3.5300 & 2.705 & $0.009 *$ \\
\hline
\end{tabular}

${ }^{*} p<0.05 ;{ }^{* *} p<0.001$

The results of T-test performed according to the position in the company (service employees or management) are shown in Table 4. Participants that work at supervisor or manager positions are more satisfied with dimension Work content than participants who work at frontline service positions. Reason may be the fact that many of those who are employed at frontline positions actually have a faculty degree and they consider themselves qualified for better or managerial positions. They probably wish to be at some position where they can stand out by the knowledge and skills they have. This can also explain the results for dimension Personal.

Apparently, there are statistically significant differences in answers for dimension Payment. Managers perform various tasks, their job is complex and they have more responsibilities than employees at frontline service positions so their salary is in accordance with that.

When building carrier in hospitality industry it usually starts at bottom level position, so employee could gain work experience. Employees have to gain work experience and to prove their abilities in order to get promoted. Having this in mind, it is obvious why those who work as supervisors and managers gave higher ratings to dimension Promotion. In fact, the biggest 
difference in answers between these two groups of participants is for this particular dimension.

Statistically significant difference is visible in answers for dimension Supervisor, where those who work as managers gave higher ratings. This can be explained in way that they can better understand managers at higher positions and their requirements as they are managers themselves.

Table 4. T-test according to the position in the company

\begin{tabular}{|l|c|c|c|c|}
\hline \multirow{2}{*}{ Dimensions } & \multicolumn{2}{|c|}{ Mean } & \multirow{2}{*}{$\mathrm{t}$} & \multirow{2}{*}{$\mathrm{P}$} \\
\cline { 2 - 5 } & Management & Executive position & & \multirow{2}{*}{$0.000^{* *}$} \\
\hline D1-Work content (satisfaction) & 4.0667 & 3.4103 & 3.794 & $0.009^{*}$ \\
\hline D2-Payment (satisfaction) & 3.4833 & 2.5313 & 0.892 & $0.000^{* *}$ \\
\hline D3-Promotion (satisfaction) & 4.0000 & 2.6667 & 0.635 & $0.003^{*}$ \\
\hline D7-Personal (satisfaction) & 4.1000 & 3.0625 & 0.371 & $0.024^{*}$ \\
\hline D8-Supervisor (satisfaction) & 4.2667 & 3.6938 & 0.910 & \\
\hline
\end{tabular}

${ }^{*} p<0.05 ;{ }^{*} p<0.001$

At the end of the survey participants had an extra question "I am thinking about changing my current job" with two possible answers (yes or no). The results showed that participants who are thinking about changing the current job, manifest dissatisfaction across all dimensions of the survey Satisfaction scale (Table 5). This is also confirmed by results of the online survey conducted in the US that the most dissatisfied employees are those who chose to leave their jobs (Stamolampros et al., 2019).

Table 5. T-test according to opinion of respondents about changing current job

\begin{tabular}{|l|c|c|c|c|}
\hline \multirow{2}{*}{ Dimensions } & \multicolumn{2}{|c|}{ Mean } & \multirow{2}{*}{$\mathrm{t}$} & $\mathrm{P}$ \\
\cline { 2 - 5 } & Changing job-Yes (n=33) & Changing job-No (n=22) & & \\
\hline D1-Work content (satisfaction) & 3.3191 & 3.9947 & -4.998 & $0.000^{* *}$ \\
\hline D2-Payment (satisfaction) & 2.3333 & 3.4773 & -3.795 & $0.000^{* *}$ \\
\hline D3-Promotion (satisfaction) & 2.3333 & 4.0758 & -6.880 & $0.000^{* *}$ \\
\hline D4-Recognition (satisfaction) & 2.4318 & 3.8182 & -4.215 & $0.000^{* *}$ \\
\hline D5-Working conditions (satisfaction) & 2.7071 & 3.2727 & -2.148 & $0.036^{*}$ \\
\hline D6-Benefits (satisfaction) & 2.6263 & 3.8636 & -3.941 & $0.000^{* *}$ \\
\hline D7-Personal (satisfaction) & 2.9848 & 3.8864 & -2.953 & $0.005^{*}$ \\
\hline D8-Supervisor (satisfaction) & 3.4470 & 4.4545 & -5.789 & $0.000^{* *}$ \\
\hline
\end{tabular}

${ }^{*} p<0.05 ;{ }^{* *} p<0.001$

Lastly, T-test according to expectations and satisfaction for all eight dimensions of the survey was performed. Unfortunately, results showed that there are statistically significant differences for each dimension between expectations that participants had before employment in hospitality industry and their satisfaction with employment in the same industry. The question is what employers could do and how could they motivate employees in order to increase their satisfaction level. Employers should be aware of importance of employees in hospitality industry and their satisfaction, because it is well known that there is a strong relationship between satisfied employee and satisfied guest. 


\section{Results of analysis of variance ANOVA}

The application of the ANOVA analysis and LSD post-hoc test examined differences between dependent variables (questions related to expectation and satisfaction with the employment in the hospitality industry) and independent variables (socio-demographic characteristics of the respondents). The results revealed statistically significant differences in respondents' responses in relation to the length of work experience in the hospitality industry of the respondents, their level of education, and the hospitality sector in which the respondents are employed.

According to the length of work experience in the hospitality industry, the results of the analysis of variance ANOVA show statistically significant differences in responses (Table 6).

Respondents who work up to a year in the hospitality industry, as well as those who work up to three years, gave the lowest ratings to dimension Payment. The reason for this can be found in the fact that wage increases with the length of experience that employee has in the hospitality industry, time spent in the company as well as with the skills and qualifications that a person possesses. Experience of employees in the industry such as hospitality is very important so respondents who work up to six years in the hospitality industry have provided the highest average rating concerning other categories of respondents, for this dimension. It is believed that during that period they progressed, and accordingly achieved financial benefits. Years of experience usually lead to higher positions as well as to greater responsibilities. However, employees with greater responsibilities also expect to receive higher salaries. The problem in the hospitality industry is that earnings are low even at the highest and most responsible positions, so it is not surprising the fact that respondents who work up to nine years in the industry did not give the highest average score to the dimension Payment.

All the above mentioned explains also the results related to the dimension Promotion. Accordingly, respondents who work up to a year and those who work up to three years in the hospitality industry, presumably still work at executive positions until they gain enough experience to progress.

The results show that respondents rated the dimension Recognition in the same manner as previously explained. The third group of respondents, those who work up to six years in the hospitality industry, for this dimension gave the highest average rating.

Dimension Personal includes statements "I am given work in accordance with my qualifications and skills" and "I work in the department of my choice". As expected, the lowest average score for this dimension is given by the respondents who work up to a year in the hospitality industry, and have lack of experience, skills and qualifications. On the other hand, respondents who have up to six years of experience in the hospitality industry, with necessary qualifications and skills, agree that they can choose in which sector of the company they can work and they gave the highest average marks.

Table 6. Analysis of variance ANOVA according to the length of work experience in the hospitality industry

\begin{tabular}{|c|c|c|c|c|c|c|c|}
\hline \multirow[b]{2}{*}{ Dimensions } & \multicolumn{4}{|c|}{ Length of work experience in the hospitality industry } & \multirow[b]{2}{*}{$\mathrm{F}$} & \multirow[b]{2}{*}{$\mathrm{P}$} & \multirow{2}{*}{$\begin{array}{l}\text { LSD Post- } \\
\text { hoc test }\end{array}$} \\
\hline & $\begin{array}{l}\text { (1) Up to a } \\
\text { year }\end{array}$ & $\begin{array}{l}\text { (2) Up to } \\
\text { three years }\end{array}$ & $\begin{array}{l}\text { (3) Up to six } \\
\text { years }\end{array}$ & $\begin{array}{l}\text { (4) Up to } \\
\text { nine years }\end{array}$ & & & \\
\hline D2-Payment (satisfaction) & 2.5000 & 2.6293 & 3.6000 & 2.8125 & 1.950 & $0.031 *$ & $1,2<3$ \\
\hline D3-Promotion(satisfaction) & 2.6667 & 2.9080 & 3.9667 & 2.6667 & 2.613 & $0.020 *$ & $1,2,4<3$ \\
\hline D4-Recognition(satisfaction) & 3.0000 & 2.6897 & 4.1000 & 2.3125 & 3.383 & $0.025^{*}$ & $2,4<3$ \\
\hline D7-Personal(satisfaction) & 2.8333 & 3.4138 & 3.8500 & 3.1250 & 1.464 & $0.048^{*}$ & $1<3$ \\
\hline
\end{tabular}

${ }^{*} p<0.05$ 
The results of the analysis of variance ANOVA according to the level of education acquired show that there are statistically significant differences in responses of participants regarding dimension Benefits. Respondents who are still students gave lower average ratings $(M=2.2500)$ than respondents who have bachelor's degree $(\mathrm{M}=3.4510)$ and that manifests that statistically significant difference exists between them $(\mathrm{F}=2.2556, \mathrm{p}=0.029)$.

Statistically significant differences in the responses of participants can be seen in the results obtained by analysis of variance ANOVA according the hospitality sector in which the respondents are employed (Table 7).

It may be noted that the respondents who are employed in departments Reception and Marketing and sales had higher expectations of Work content than those who are employed in the department Kitchen. The reason for this may be that job in the sectors Reception and Marketing and sales include a wide range of different tasks and activities. Besides that, studies show that employees in the kitchen feel undervalued and they find their job boring (Murray-Gibbons, Gibbons, 2007). However, if the attention is paid to the results of satisfaction with the dimension of Work content, it is evident that the lowest average grade is given by the respondents employed in the Restaurant, while significantly different assessment is given by the respondents employed in the Reception. This may represent the fact that jobs in the Restaurant are based on service, while jobs in the sector Reception include various tasks such as communication, administration, reservations, etc. It is very common situation that in sector Restaurant do not work employees with proper qualifications and professional orientation (Kosar, 2009).

While respondents who work in Kitchen department gave the lowest average score for expectations for the dimension Promotion, respondents who are employed in the Reception had the highest expectations for the same dimension, compared to employees in other sectors.

Statistically significant differences in the responses can be observed with the dimension Benefits, (expectations scale). Differences in responses occur between employees in the Restaurant sector, who had lower expectations than employees in the Reception.

According to data of the Statistical Office of the Republic of Serbia from 2019, the wage of employees in restaurants and hotels is extremely low. The highest average score for dimension Payment was given by participants employed in the sector Restaurant. Practice shows that it is not uncommon that employees in this sector, in addition to their regular salaries or wages, receive additional income/bonus from the employer or tips from guests directly, due to the good services they provide. On the other hand, employees in the sector Kitchen gave the lowest average score for the same dimension. Dissatisfaction with salaries was recognized as one of the main sources of stress of chefs at work, followed by treatment by managers, pressures at work and working time per day (Smith, Carroll, 2006).

The results obtained for the dimension Working conditions show the lowest average rating from the Restaurant sector staff, while the highest average grade is given by employees from sectors Reception and Marketing and sales. The explanation can be found in the way of functioning of the restaurant, where it is understood that the restaurant is open until the guests are in it.

While respondents who are employed in the sector Restaurant disagree or neither agree or disagree with satisfaction of dimension Personal which includes statements "I am given work in accordance with my qualifications and skills" and "I work in the department of my choice", respondents from the sector Reception gave the highest average marks to this dimension. Employees in the Restaurant sector may not be satisfied with the sector where they work and with the job they do. 
Table 7. Analysis of variance ANOVA according to the hospitality sector in which respondent is employed

\begin{tabular}{|c|c|c|c|c|c|c|c|}
\hline \multirow[b]{2}{*}{ Dimension } & \multicolumn{4}{|c|}{ The hospitality sector in which respondent is employed } & \multirow[b]{2}{*}{$\mathrm{F}$} & \multirow[b]{2}{*}{$P$} & \multirow{2}{*}{$\begin{array}{l}\text { LSD Post- } \\
\text { hoc test }\end{array}$} \\
\hline & $\begin{array}{c}(1) \\
\text { Kitchen }\end{array}$ & $\begin{array}{c}\text { (2) } \\
\text { Restaurant }\end{array}$ & $\begin{array}{c}\text { (3) } \\
\text { Reception }\end{array}$ & $\begin{array}{l}\text { (4) Marketing } \\
\text { and sales }\end{array}$ & & & \\
\hline D1-Work content (expectation) & 3.6863 & 3.8452 & 4.1230 & 4.3059 & 3.186 & $0.031^{*}$ & $1<3,4$ \\
\hline D3-Promotion (expectation) & 4.1111 & 4.5263 & 4.7273 & 4.6667 & 1.791 & $0.027^{*}$ & $1<3$ \\
\hline $\begin{array}{l}\text { D5-Working conditions } \\
\text { (expectation) }\end{array}$ & 3.4074 & 3.3158 & 3.9091 & 3.8667 & 2.636 & $0.013^{*}$ & $2<3$ \\
\hline D6-Benefits (expectation) & 3.9259 & 3.4737 & 4.2576 & 4.1333 & 2.261 & $0.014^{*}$ & $2<3$ \\
\hline D1-Work content (satisfaction) & 3.4837 & 3.2755 & 3.8396 & 3.8706 & 3.486 & $0.022 *$ & $2<3$ \\
\hline D2-Payment (satisfaction) & 1.9444 & 3.0789 & 2.8750 & 2.8500 & 1.918 & $0.023^{*}$ & $1<2$ \\
\hline $\begin{array}{l}\text { D5-Working conditions } \\
\text { (satisfaction) }\end{array}$ & 2.8519 & 2.4035 & 3.3333 & 3.3333 & 3.836 & $0.015^{*}$ & $2<3,4$ \\
\hline D7-Personal (satisfaction) & 3.4444 & 2.8947 & 3.6818 & 3.4000 & 1.579 & $0.036^{*}$ & $2<3$ \\
\hline
\end{tabular}

${ }^{*} p<0.05$

\section{Conclusion}

The topic related to employee satisfaction is very interesting, many studies have been conducted about it and it was the focus of interest of many authors. Taking into consideration that the hospitality industry is very specific, mainly because it is based on service, it can be concluded that the combination of these two topics provides a very convenient and interesting base for research.

The fact that mostly there are no established human resource departments, especially in small hotels and restaurants, represents a big problem in the hospitality industry of the Republic of Serbia. Those departments would deal with employees, innovations, trainings, new technologies, etc. For the employees in this industry is necessary to keep acquiring new knowledge and skills, and this can be achieved through various forms of continuous education and training. Those who should initiate and provide the necessary training are certainly employers.

The research results showed that the respondents had high expectations about the job, which is considered adequate for people who have a university degree, but the real picture shows that respondents were dissatisfied with payments, recognition, and working conditions. All of the above negatively affects the attractiveness of employment in the hospitality industry as well as a lack of motivation of employees in this industry. According to data of the Statistical Office of the Republic of Serbia from 2019 salaries and benefits of employees in the hospitality industry in the Republic of Serbia are devastatingly low, actually among 19 different industry sectors employees in the hospitality industry have the lowest average salary.

Managers in tourism and the hospitality industry have difficulty hiring new employees and also struggle with retention of qualified, competent, organized and motivated employees in companies. Employee satisfaction should be an imperative for all companies since employees deliver service quality that guests pay for, so it can be said that employees generate income.

There are few limitations of the study. Firstly, the study is done just on the sample of current and former students of Faculty of Sciences in Novi Sad, Republic of Serbia. Secondly, all respondents are in the 21-30 age range. Finally, it is assumed that all respondents are employed in Novi Sad or in Vojvodina. Suggestion for further research would include a new conduc- 
tion within the entire Republic of Serbia, which will focus on a bigger and more diverse sample. Lastly, the results of such study would allow an insight into employees' job satisfaction and further lead to necessary measures that should bridge this gap in hospitality sector, raising the awareness about importance of human resources at the same time.

\section{References}

Blagojević, S., Redžić, V. 2009. Employment in the hotel industry in the Republic of Serbia as an indicator of the state of human resources in the domestic hotel industry. Researches Review of the Department of Geography, Tourism and Hotel Management 38/2009, 252264. (in Serbian)

Cheng, J., O-Yang, Y. 2018. Hotel employee job crafting, burnout, and satisfaction: The moderating role of perceived organizational support. International Journal of Hospitality Management 72, 78-85.

De Beer, M. J. 1987. Ondersoek an die rol wat arbeidsomset in die bedryfspeel met spesifieke verwysing na werkberverdiging en werksmotivering. University of the Free State-Bloemfontein. (in Dutch)

Đeri, L. 2009. Human resources problems in tourism. Hotellink 10(13-14), 988-993. (in Serbian)

Groth, M., Henning-Thurau, T., Walsh, G. 2009. Customer reactions to emotional labor: The roles of employee acting strategies and customer detection accuracy. Academy of Management Journal 52(5), 958-974.

Hartline, M.D., Ferrel, O.C. 1996. The management of customer-contact employees: An empirical investigation. Journal of Marketing 6o(4), 52-70.

Hinton, P.R., McMurray, I., Brownlow, C. 2004. Explained. Routledge: Taylor \& Francis-New York.

Holmes, M. 2019. Why are there so few women CEOs? Available online: http://theconversation. com/why-are-there-so-few-women-ceos-103212. (Accessed on: 10.01.2020.)

Karatepe, O.M., Babakus, E., Yavas, U. 2012. Affectivitty and organizational politics as antecedents of burnout among frontline hotel employees. International Journal of Hospitality Management 31(1), 66-75.

Karatepe, O.M., Bekteshi, L. 2008. Abtecedents and outcomes of work-family facilitation among frontline hotel employees. International Journal of Hospitality Management 27, 517-528.

Karatepe, O.M., Kilic, H., Isiksel, B. 2008. An examination of the selected antecedents and outcomes of work-family conflict and family-work conflict in frontline service jobs. Service Marketing Quarterly 29(4), 1-24.

Karatepe, O.M., Uludag, O. 2008. Affectivity, conflicts in the work-family interface, and hotel employee outcomes. International Journal of Hospitality Management 27(1), 30-41.

Kim, H.J., 2008. Hotel service providers' emotional labor: The antecedents and effects on burnout. International Journal of Hospitality Management 27(2), 151-161.

Knox, S., Maklan, S., Payne, A., Ryals, L. 2003. Customer Relationship Management. Butterworth-Heinemann, Oxford.

Kong, H., Jiang, X., Chan, W., Zhou, X. 2018. Job satisfaction research in the field of hospitality and tourism. International Journal of Contemporary Hospitality Management 30(5), 2178-2194. 
Kosar, Lj., Rašeta, S, (2005). Quality challenges - Quality management in the hotel industry. College of Hotel Management, Belgrade. (In Serbian)

Kosar, Lj. 2009. The impact of employee satisfaction on the quality of hotel services. Hotellink 10(13-14), 931-936. (in Serbian)

Lee, J.J., Ok, C. 2012. Reducing burnout and enchacing job satisfaction: Critical role of hotel employees' emotional intelligene and emotional labor. International Journal of Hotel Management 31(4), 1101-1112.

Macdonald, C. L., Sirianni, C. 1996. Working in the Service Society. Temple University PressPhiladelphia.

McPhail, R., Patiar, A., Herington, C., Creed, P., Davidson, M. 2015. Development and initial validation of a hospitality employees' job satisfaction index: Evidence from Australia. International Journal of Contemporary Hospitality Management 27(8), 1814-1838.

Murray-Gibbons, R., Gibbons, C. 2007. Occupational stress in the chefs profession. International Journal of Contemporary Hospitality Management 19, 32-42.

O'Neill, J., Xiao, Q. 2010. Effects of organizational/occupational characteristics and personality traits on hotel manager emotional exhaustion. International Journal of Hospitality Management 29(4), 652-658.

Reisch, R. 2017. The Ideal Mom, the ideal worked, and our dehumanizing expectations of women. Available online: https://iheartintelligence.com/ideal-mom-expectations-of-women/. (Accessed on: 10.01.2020.)

Statistical Office of the Republic of Serbia, 2018. Press Release No. 6, Statistics. Available online: https:/publikacije.stat.gov.rs/G2018/Pdf/G20181006.pdf (Accessed on: 27.03.2020.)

Statistical Office of the Republic of Serbia, 2019. Press Release No. 94, Statistics. Available online: http://publikacije.stat.gov.rs/G2019/pdf/G20191094.pdf (Accessed on: 27.03.2020.)

Smith, M., Carroll, M. 2006. Working conditions in the HORECA sector: Spanish Report. European Foundation for Improvement of Working and Living conditions-Dublin.

Smith, T.W. 2007. Job satisfaction in the United States. NORC/University of Chicago.Available online: http://www-news.uchicago.edu/releases/o7/pdf/070417.jobs.pdf. (Accessed on: 22.08.2019.)

Stamolampros, P., Korfiatis, N., Chalvatzis, K., Buhalis, D. 2019. Job satisfaction and employee turnover determinants in high contact services: Insights from Employees' Online reviews. Tourism Management 75, 130-147.

Tsai, W. C. (2001). Determinants and consequences of employee positive emotions. Journal of Management, 27(4), 497-512.

Tsai, W. C., Huang, Y. M. (2002). Mechanism linking employee affective delivery a customer behavioral intentions. Journal of Applied Psychology, 87(5), 1001-1008.

U.S. Bureau of Labor Statistics, 2020. Annual quits rates by industry and region, not seasonally adjusted. Available on: https://www.bls.gov/news.release/jolts.t18.htm (Accessed on: 29.03.2020)

Walker, J. R. 2007. Exploring the Hospitality Industry. Pearson Prentice Hall-New Jersey. 